\title{
Pannyhis şi Orthros: formularul liturgic cu „Aliluia” şi pomenirea morţilor în perioada Octoihului
}

\section{Cezar LOGIN*}

\begin{abstract}
Pannychis and Orthros: The Liturgical Formulary with "Alleluia" and The Commemoration of the Deceased During The Time of The Octoechos. During the liturgical week, Saturdays have an intermediate place between weekdays (Monday-Friday) and Sundays. The liturgical theme of the Saturday celebrations is double: the commemoration of all Saints and all the departed, with the focus on one theme or the other. This specific situation lead to the existence of two different liturgical structures for a Saturday celebration. The first, resembling the usual weekday order - during which at Matins is sung The Lord is God... -, is frequently used; the second - during which at Matins is sung Alleluia -, has become almost obsolete, probably as a consequence of the difficulties related to its celebration. The present study intends to present an algorithm which allows the identifications of the liturgical days when Alleluia services might be celebrated, to perform a brief analysis of the structure of these celebrations, and to identify the system according to which hymns are distributed across these liturgical celebrations.
\end{abstract}

Keywords: Saturday, requiem service, Alleluia celebration, Matins, Pannychis.

\section{Introducere}

În cadrul săptămânii liturgice, sâmbăta nu este considerată una dintre zilele „de rând” ale săptămânii - denumire rezervată

* Doctor în Teologie al Universității „Babeș-Bolyai”, Lect. univ. la Facultatea de Medicină a Universității de Medicină și Farmacie „Iuliu Hațieganu” din ClujNapoca. 
pentru zilele de luni-vineri -, ci ocupă un loc ,intermediar” între zilele de rând şi duminică, având un caracter festiv: sâmbăta se aduce întotdeauna Jertfa Euharistică, celebrându-se Liturghia deplină a Sfântului Ioan Hrisostom sau a Sfântului Vasile cel Mare. Mai mult, caracterul special al sâmbetei în cadrul timpului liturgic este subliniat şi de faptul că sâmbăta, similar duminicii, nu se fac metanii şi, de asemenea, nu este permisă ajunarea (canonul 66 apostolic) ${ }^{1}$.

În afara cazului în care se întâmplă o sărbătoare (situaţie în care formularul liturgic al sâmbetei este înlocuit complet de cel al sărbătorii) ${ }^{2}$, sâmbătă are, pe parcursul întregului an liturgic, un caracter dublu: (1) pomenirea mucenicilor, cuvioşilor şi a tuturor sfinţilor şi (2) pomenirea tuturor celor adormiţi. Acest caracter este evident în apolisul rostit la Vecernia, Utrenia şi Liturghia de sâmbătă: „Hristos, Adevăratul Dumnezeul nostru, pentru rugăciunile preacuratei Maicii Sale, ale sfinţilor, slăviţilor şi întru tot lăudaţilor apostoli, ale sfinţilor, slăviţilor bunilor biruitori mucenici, ale preacuvioşilor şi de Dumnezeu purtătorilor părinţilor noştri [...] şi pentru ale tuturor sfinţilor"3. Totuşi, accentul comemorării de sâmbăta poate înclina într-un sens sau altul, predominând pomenirea tuturor sfinţilor sau pomenirea celor adormiţi, situaţie ce a condus la existenţa actuală a două tipuri de oficii liturgice care se pot celebra sâmbăta: (1) slujbă cu Dumnezeu este Domnul..., cu o rânduială asemănătoare zilelor de rând, şi (2) slujbă cu Aliluia, în care pomenirea celor adormiţi dobândeşte un caracter mai evident, derularea celebrării deosebindu-se de cea a zilelor de rând (chiar şi atunci când în zilele de rând se cântă

${ }^{1}$ Ioan Nicolae FlocA, Canoanele Bisericii Ortodoxe, Sibiu, 1992, p. 155.

${ }^{2}$ Este vorba de slujbele cu priveghere: ,dacă s-ar întâmpla Sâmbătă vreun Praznic Stăpânesc, atunci se cântă neschimbată toată Slujba Praznicului” (***Tipicon, Iaşi, Tipografia Sfintei Mitropolii, 1816, pp. 26, 29-30), de slujbele cu Polieleu (ibidem, pp. 29-30) şi de formularele liturgice ale perioadelor festive (înainteşi dupăprăznuire) (ibidem). În continuare, textul citatelor preluate din ediţia princeps românească a Tipiconului Mare al Sfântului Sava (Iaşi, 1816) sunt transliterate şi îndreptate din punct de vedere al ortografiei contemporane.

3 ***Liturghier, Bucureşti, Edit. Institutului Biblic şi de Misiune Ortodoxă, 2000, p. 351. 
Aliluia $^{4}$ ). Însă formularul de slujbă cu Aliluia, cu o desfăşurare mai complexă, aproape că a fost împins în desuetudine, fiind extrem de rar celebrat - chiar omis complet! -, cu excepţia sâmbetelor a doua, a treia şi a patra din Postul Mare ${ }^{5}$, care au păstrat, evident, vechiul caracter al slujbelor de sâmbăta.

Asupra acestui formular liturgic ,special” intenţionăm să ne oprim în acest studiu, cu speranţa retrezirii interesului pentru acest tip de celebrare - care se poate constitui atât structural, cât şi în ceea ce priveşte imnografia într-o veritabilă cateheză liturgică cu privire la cei adormiţi - şi pentru revigorarea folosirii sale în cult.

\section{Care sunt zilele de sâmbătă în care se cântă slujbă cu Aliluia?}

În partea generală a Tipiconului savait - Tipicul Mare - zilei de sâmbătă îi sunt dedicate două capitole. Unul dintre ele descrie slujbele cu Dumnezeu este Domnul... (capitolul 14) ${ }^{6}$, iar celălalt descrie slujbele cu Aliluia (capitolul 15) ${ }^{7}$. Tot în legătură cu celebrările de sâmbătă, acestor capitole li se adaugă capitolul 16, ce descrie rânduiala Parastasului pentru cei morţi ${ }^{8}$, ultimele două paragrafe ale capitolului 13 , ce reglementează cântarea canoanelor Utreniei de sâmbătă în cazul în care în Minei este indicată o celebrare simplă sau dublă (un sfânt cu slujba «pe 4» sau doi sfinţi

${ }^{4}$ Pentru formularul liturgic al zilelor de rând cu Aliluia în afara Postului Mare şi pentru o analiză detaliată a originii şi dezvoltării lor, a se vedea: Cezar LoGIN, Înainteprăznuirea Naşterii Domnului în ritul bizantin, col. „Liturgica”, 17, Cluj-Napoca, Edit. Renaşterea, 2020, pp. 99-117; cf. IDEM, „Slujbele cu «Aliluia» în Posturile mici: actuale sau desuete?", în IDEM, Leitorugia: teologie şi practică liturgică, col. „Liturgica”, 14, Cluj-Napoca, Edit. Renaşterea, 2014, pp. 103-127.

5 Şi în aceste trei situaţii, în practica bisericilor parohiale, s-a păstrat doar celebrarea Sfintei Liturghii şi a Parastasului (Panihidei) imediat după otpustul acesteia, „liturghia timpului”, Utrenia (cel puţin) fiind, în cele mai multe cazuri, omisă.

$6 * * *$ Tipicon (1816), pp. 25-26.

${ }^{7}$ Ibidem, pp. 27-28.

${ }^{8}$ Ibidem, pp. 28-30. 
cu slujba «pe 6») ${ }^{9}$ sau o celebrare cu doxologie mare cântată (observaţia de la finalul capitolului) ${ }^{10}$, precum şi capitolul 17, care descrie soluţia tipiconală pentru coincidenţa zilei de sâmbătă cu o celebrare mineală cu Polieleu sau cu Priveghere, dar şi coincidenţa cu perioada festivă a unui praznic al Mântuitorului sau al Maicii Domnului (înainteprăznuire sau dupăprăznuire) ${ }^{11}$.

Prima „observaţie” a capitolului 14 afirmă:

„Se cuvine a şti: Că de nu se va întâmpla vreo pomenire a vreunui Apostol sau a vreunuia din sfinţii cei mari, ori a vreunui sfânt care nu are tropar, Dumnezeu este Domnul... nu cântăm, ci Aliluia, pe glasul al 2-lea""12.

Coroborând această rubrică cu indicaţiile tipiconale din celelalte capitole menţionate, putem identifica zilele de sâmbătă în care este posibilă utilizarea formularului liturgic cu Aliluia pentru liturghia timpului ${ }^{13}$ :

- să nu ne găsim în interiorul perioadei festive a vreunui praznic al Mântuitorului sau al Născătoarei de Dumnezeu ${ }^{14}$;

- în Minei să fie o celebrare simplă (un sfânt cu slujba «pe 4») sau dublă (doi sfinţi cu slujba «pe 6»);

- să nu existe în Minei formular liturgic cu tropar „propriu”15;

- să nu fie pomenirea unui sfânt apostol ${ }^{16}$.

Chiar dacă toate aceste condiţii sunt îndeplinite, tipul de celebrare rămâne la latitudinea ,celui mai mare”, după cum se

${ }^{9}$ Ibidem, p. 24.

${ }^{10}$ Ibidem, p. 25.

${ }^{11}$ Ibidem, pp. 30-31.

12 Ibidem, p. 25.

13 Cf. Daniel Olson, „The Saturday Requiem Service”, în Peter FeKula și Matthew Williams, The Order of Divine Services according to the usage of the Russian Orthodox Church, 2009², St. John of Kronstadt Press, Liberty, pp. 249-256.

14 Înainteprăznuire, praznic, dupăprăznuire şi odovanie.

15 Adică formularul mineal să nu indice un tropar ,de obşte”, dintre cele existente în anexa Mineielor.

16 În acest caz, chiar dacă este indicat tropar de obşte pentru apostoli, totuşi nu se cântă slujbă cu Aliluia, ci cu Dumnezeu este Domnul. 
observă din titlul capitolului 15 al Tipiconului: „Pentru că se cade a şti. Că de se va întâmpla şi de va voi cel mai mare Sâmbăta a cânta Aliluia"17.

În perioada Triodului ${ }^{18}$ sunt prevăzute patru astfel de zile în care se face pomenirea celor adormiţi: sâmbăta lăsatului sec de carne („,moşii de iarnă”) ${ }^{19}$ şi sâmbetele a 2-a, a 3-a şi a 4-a din Postul Mare ${ }^{20}$, cunoscute în tradiţia grecească ca ,sâmbetele sufletelor" $(\psi v \chi o \sigma \alpha ́ \beta \beta \alpha \tau o)^{21}$.

În perioada Penticostarului există o singură astfel de zi: Sâmbăta Rusaliilor („moşii de vară”), cu formular liturgic cvasiidentic cu cel al Sâmbetei lăsatului sec de carne ${ }^{22}$. În ambele

$17 * * *$ Tipicon (1816), p. 27.

${ }^{18} \mathrm{Nu}$ se celebrează slujbă cu Aliluia şi nu se face pomenirea specială a celor adormiţi în Sâmbăta lăsatului sec de brânză (Sâmbăta asceţilor) - celebrare cu doxologie mare cântată (***Triodul, Bucureşti, Edit. Institutului Biblic şi de Misiune Ortodoxă, 2010, p. 100) -, în sâmbăta întâi din Post (Sâmbăta Sfântului Teodor - formular liturgic cu tropar propriu) (ibidem, p. 194), sâmbăta a 5-a din Post (Sâmbăta Imnului Acatist) - praznic cu doxologie mare cântată (ibidem, p. 465) şi nici în Sâmbăta Sfântului şi Dreptului Lazăr (celebrare anastasică şi cu doxologie mare cântată) (ibidem, pp. 520-529), cu care începe deja perioada praznicelor (cf. Nicolae D. NECULA, Tradiţie şi înnoire în slujirea liturgică, vol. I, Bucureşti, Edit. Trinitas, 2014, pp. 782784). În acest sens, în Triodul slavon prenikonian, ce reflectă probabil unele practici greceşti mai vechi, Sâmbăta lui Lazăr nu făcea parte din Triodul postului, ci din Triodul , înflorit”, adică Triodul festiv (spre ex., ***Tpuodb Цветная, Москва, 1635, ff. $2^{\mathrm{r}}-26^{\mathrm{r}}$ ). Şi în Triodul slavon postnikonian, Sâmbăta lui Lazăr nu este inclusă în primul volum al Triodului postului (care conţine doar „Patruzecimea” şi se încheie cu Pavecerniţa de vineri din săptămâna a şasea din Post), ci se găseşte în deschiderea volumului al doilea al Triodului postului (***Tріод Постная, т. 2, Москва, 1992, ff. 386 ${ }^{\mathrm{r}}-393^{\mathrm{r}}$ ).

$19 * * *$ Triodul (2010), pp. 27-40.

${ }^{20}$ Ibidem, pp. 252-258, 307-311, 370-374.

21 Dacă în aceste sâmbete se întâmplă o celebrare mineală cu doxologie mare cântată (spre ex., Sfinţii 40 de Mucenici, 9 martie, § V.o etc.) sau perioada festivă a Bunei Vestiri (24-26 martie, §§ VI.1.f, 2.b, j, k etc.) atunci nu se mai face pomenirea morţilor, ci este o celebrare festivă (cu Dumnezeu este Domnul...); a se vedea „Învăţătura de Tipic a lui Marcu” din anexa Triodului (2010), pp. 779-818, mai ales: pp. 780, 786-787, 793, 800-801 etc.

$22 * * *$ Penticostar, Bucureşti, Edit. Institutului Biblic şi de Misiune Ortodoxă, 2012, pp. 303-318. 
situaţii, există şi o serie de particularităţi (tropar propriu etc.) care nu vor fi abordate aici, dar care au influenţat structura actuală a Slujbei de înmormântare și cea a Parastasului (Panihida).

În perioada Octoihului există numeroase zile în care este posibilă utilizarea formularului liturgic cu Aliluia. Totuşi, în actualitate practica folosirii acestui formular în respectivele zile a devenit desuetă, în marea majoritate a cazurilor formularul fiind folosit exclusiv în sâmbăta cunoscută sub denumirea populară de ,moşii de toamnă",23 sau nici măcar atunci. În continuare va fi abordată structura slujbelor cu Aliluia exclusiv pentru perioada Octoihului.

\section{Structura slujbelor cu Aliluia pentru zilele de sâmbătă din perioada Octoihului}

Formularul liturgic complet include Vecernia, Pavecerniţa, Miezonoptica, Utrenia, Ceasurile şi Dumnezeiasca Liturghie, la care se adaugă şi săvârşirea Panihidei (Parastasului mare) care, într-o oarecare măsură, se constituie ca o dublare parţială atât a Pavecerniţei Mari, cât şi a Utreniei actuale. Vom reda şi vom analiza structura fiecărei celebrări descrise de Tipiconul savait (capitolul 15) în raport cu celebrările sâmbetelor cu Dumnezeu este Domnul... şi, unde este cazul, în raport cu formularul liturgic al zilelor din perioada Triodului şi Penticostarului menţionate mai sus. Analiza priveşte, în primul rând, structurile liturgice şi distribuţia imnografiei şi, în mai mică măsură, conţinutul imnurilor selectate ${ }^{24}$.

\subsection{Vecernia $^{25}$}

Sinaxa de seară urmează planul obişnuit al Vecerniei zilelor de rând. Particularităţile acestui oficiu privesc exclusiv selecţia

23 În marea majoritate a cazurilor sâmbăta dinaintea sărbătorii Sfinţilor Arhangheli

(în practica românească); a se vedea, spre ex., calendarul bisericesc anual.

24 Analiza conţinutului imnografiei prolifice din diversele ediţii tipărite greceşti, slavone şi româneşti ale cărţilor de cult sperăm că va face obiectul unui studiu separat.

$25 * * *$ Tipicon (1816), pp. 25 şi 27. 
imnografiei. Structura actuală a Octoihului mare românesc face dificilă identificarea stihirilor, căci imnografia Octoihului contemporan nu mai este în concordanţă cu rubricile Tipiconului savait; mai mult, există diferenţe semnificative între poziţionarea uneia sau a altei categorii de imnuri în cadrul diverselor glasuri. Interesant de remarcat, în ceea ce priveşte imnografia sâmbetelor este faptul că anexa Triodului, ce conţine o parte selectată din Octoih, respectă îndeaproape rubricile din Tipicon, reflectând, probabil, o redactare mai veche. Va fi analizată imnografia de la Doamne, strigat-am ..., de la stihoavnă şi troparele.

La Doamne, strigat-am..., se cântă şase stihiri. Datorită faptului că slujba sâmbetei încheie slujbele fiecărui glas, la Slavă... Şi acum... se cântă întotdeauna stihira Născătoarei de Dumnezeu „,cea dintâi” a glasului de rând ${ }^{26}$. Stihirile folosite variază în funcţie de tipul de celebrare:

\begin{tabular}{|c|c|}
\hline Aliluia & Dumnezeu este Domnul... \\
\hline - 3 stihiri din Minei; & - 6 stihiri din Minei ${ }^{27}$ \\
\hline - 3 stihiri martirice din Octoih (a & - Slavă..., a Sfântului (dacă \\
\hline 2-a, a 3-a şi a 4-a), prima nu se & există); \\
\hline zice; & - Şi acum..., a Născătoarei de \\
\hline - Slavă... Şi acum..., a & Dumnezeu (cea dintâi a glasului de \\
\hline $\begin{array}{l}\text { Născătoarei de Dumnezeu (cea } \\
\text { dintâi a glasului de rând). }\end{array}$ & rând). \\
\hline
\end{tabular}

Conform Tipiconului, pentru fiecare glas există câte patru stihiri martirice (mucenicine). În „octoihul” anexat Triodului pentru fiecare seară de vineri, la Vecernie, sunt prevăzute aceste patru stihiri martirice ${ }^{28}$ şi, foarte probabil, la acest set de stihiri se referă Tipiconul. $\mathrm{Nu}$ se poate spune acelaşi lucru despre Octoihul Mare românesc contemporan, care este inconsecvent: numărul şi localizarea stihirilor martirice variază în cadrul Vecerniei; unele chiar lipsesc. Localizarea lor este următoarea:

${ }^{26}$ Denumită frecvent Dogmatică, urmând terminologia întâlnită în ediţiile slavone.

${ }^{27}$ Dacă nu sunt decât 3 stihiri, atunci se dublează fiecare dintre ele.

$28 * * *$ Triodul (2010), pp. 697-742. 


\begin{tabular}{|c|c|c|}
\hline Glas & La Doamne, strigat-am... & La stihoavnă \\
\hline 1 & - & 3 stihiri martirice $(2-3-4)^{29}$ \\
\hline 2 & - & 3 stihiri martirice $(2-3-4)^{30}$ \\
\hline 3 & - & 3 stihiri martirice $(1-2-3)^{31}$ \\
\hline 4 & - & 3 stihiri martirice $(1-2-3)^{32}$ \\
\hline 5 & 3 stihiri martirice $(2-3-4)^{33}$ & 1 stihiră martirică $(1)^{34}$ \\
\hline 6 & 3 stihiri martirice $(2-3-4)^{35}$ & 1 stihiră martirică $(1)^{36}$ \\
\hline 7 & 3 stihiri martirice $(2-3-4)^{37}$ & 1 stihiră martirică $(1)^{38}$ \\
\hline 8 & 3 stihiri martirice $(1-3-4)^{39}$ & 1 stihiră martirică $(1)^{40}$ \\
\hline
\end{tabular}

Se poate observa că pentru glasurile $1,2,3$ şi 4 avem doar trei stihiri martirice în Octoih (lipseşte prima stihiră), pentru glasurile 5, 6 şi 7 avem toate cele patru martirice, în timp ce pentru glasul al 8-lea există, în realitate, doar trei stihiri martirice: prima este dublată, în timp ce a doua lipseşte. În practică, diversitatea localizării acestor stihiri face dificilă identificarea şi îngreunează folosirea lor. Ar fi mult mai uşor de utilizat seturile complete de patru stihiri martirice - trei pentru Doamne, strigat-am... şi una pentru stihoavnă - aşa cum apar ele în anexa Triodului ${ }^{41}$.

Indiferent de tipul de slujbă, vineri seara se cântă prochimenul zilei, glasul al 7-lea, „Dumnezeule, sprijinitorul meu eşti Tu...” (Ps. 58, 21; stih: Ps. 58, 1). Ultima ediţie a Ceaslovului românesc ${ }^{42}$ indică, eronat, cântarea Aliluia în locul prochimenului. Singurele două situaţii în

29 ***Octoih Mare, Bucureşti, Tipografia Cărţilor Bisericești, 1952, p. 88.

${ }^{30}$ Ibidem, p. 177.

${ }^{31}$ Ibidem, p. 263. Prima stihiră martirică lipseşte.

32 Ibidem, p. 356. Prima stihiră martirică lipseşte.

${ }^{33}$ Ibidem, p. 445. Reprezintă al doilea set de stihiri de la Doamne, strigat-am.

${ }^{34}$ Ibidem, p. 446.

${ }^{35}$ Ibidem, p. 534. Reprezintă al doilea set de stihiri de la Doamne, strigat-am.

${ }^{36}$ Ibidem.

${ }^{37}$ Ibidem, pp. 617-618. Reprezintă primul set de stihiri de la Doamne, strigat-am.

${ }^{38}$ Ibidem, p. 618.

${ }^{39}$ Ibidem, p. 712. Reprezintă primul set de stihiri de la Doamne, strigat-am.

${ }^{40}$ Ibidem, p. 713. Este reluată prima martirică de la Doamne, strigat-am.

${ }^{41}$ A se vedea, ***Triodul (2010), pp. 697-742.

$42 * * *$ Ceaslov, Bucureşti, Edit. Institutului Biblic şi de Misiune Ortodoxă, 2014, p. 159. 
care la Vecernie se cântă Aliluia (întreit), cu stihurile sale, sunt Sâmbăta lăsatului sec de carne şi Sâmbăta Rusaliilor, în care formularul liturgic este orientat exclusiv spre pomenirea celor adormiţi ${ }^{43}$.

La stihoavnă se cântă trei stihiri, având intercalate două stihuri. În cazul în care este utilizat formularul cu Dumnezeu este Domnul... se poate presupune folosirea stihurilor obişnuite din Ceaslov (Ps. 122) ${ }^{44}$ sau a două stihuri frecvent folosite în relaţie cu stihiri ale sfinţilor mucenici (Ps. 67, 36 şi Ps. 15, 3). În cazul slujbelor cu Aliluia - subiectul nostru -, stihirile morţilor trebuie intercalate cu stihurile următoare: „Fericiţi sunt cei pe care i-ai ales şi i-ai primit, Doamne” (Ps. 64, 4); „Sufletele lor întru bunătăţi se vor sălăşlui şi seminţia lor va moşteni pământul” (Ps. 24, 14).

Pentru stihoavnă, sunt indicate următoarele stihiri ale glasului de rând:

\section{Aliluia}

- o stihiră martirică;

- două stihiri ale morţilor, ale Sfântului Ioan Damaschin;

- Slavă... Şi acum..., a Născătoarei de Dumnezeu.
Dumnezeu este Domnul...

- 3 stihiri martirice ${ }^{45}$

- Slavă..., a Sfântului (dacă există);

- Şi acum ..., a Născătoarei de Dumnezeu.

Stihirile martirice au fost deja analizate mai sus. În ceea ce priveşte stihirilor morţilor situaţia este la fel de confuză. La glasurile 1, 2, 3 şi 4 există o singură stihiră a morţilor la stihoavnă $^{46}$; la glasurile 5,6 şi 8 există două astfel de stihiri la

43 În aceste două situaţii, se cântă întotdeauna de trei ori Aliluia (întreit), glasul al 8-lea, intercalat cu două stihuri: „Fericiţi sunt cei pe care i-ai ales...” (Ps. 64, 4) şi „Sufletele lor întru bunătăţi se vor sălăşlui...” (Ps. 24, 14), a se vedea ***Triodul (2010), p. 28; cf. ***Tipicon (1816), pp. 489-490, 622. Ediţia recentă a Penticostarului românesc - ***Penticostar (2012), p. 305 - introduce aici o eroare (probabil sub influenţa structurii Utreniei acestor zile), indicând trei stihuri, deşi ediţiile anterioare au doar cele două stihuri obişnuite (spre ex., ediţia precedentă: ***Penticostar, Bucureşti, Editura Institutului Biblic şi de Misiune al Bisericii Ortodoxe Române, 1999, p. 299).

$44 * * *$ Ceaslov (2014), p. 160.

${ }^{45}$ Probabil martiricele 1, 2 şi 3.

$46 * * *$ Octoih Mare (1952), pp. 99, 177, 263, 356. 
stihoavnă ${ }^{47}$; la glasul al 7-lea există trei stihiri ale morţilor (una la Doamne, strigat-am... şi două la stihoavnă $)^{48}$. In niciunul din cazuri nu este precizat autorul compoziţiilor. Totuşi Sfântul Ioan Damaschin poate fi identificat ca autor al câte unei stihiri a morţilor pentru fiecare glas pe baza atribuirii acestor texte în cadrul slujbei înmormântării ${ }^{49}$. Stihirile morţilor din anexa Triodului ${ }^{50}$ concordă cu cele din slujba înmormântării pentru toate glasurile, cu excepţia glasului al 7-lea, unde este atribuită Sfântului Ioan Damaschin o altă stihiră (,Odihneşte, Mântuitorul nostru, Dătătorule de viaţă...”), existentă şi în Octoih la stihoavna acestui glas.

Troparele cântate la finalul Vecerniei, diferă în funcţie de tipul de celebrare:

\section{Aliluia}

Troparele generale, glasul al 2-lea:

- Apostolilor, mucenicilor şi prorocilor...

- Slavă..., Pomeneşte, Doamne, ca un bun...

- Şi acum..., al Născătoarei de Dumnezeu: Maică Sfântă... ${ }^{51}$

\section{Dumnezeu este Domnul...}

- troparul sfântului;

- Slavă..., al doilea tropar al sfântului (dacă există);

- Şi acum..., al NăscătoareiÎnvierii, al glasului de rând (?).

Vecernia este urmată de „obişnuita” litie (= procesiune) în pridvor, unde se face rugăciune pentru cei morţi ${ }^{52}$. Rubrica apare

${ }^{47}$ Ibidem, pp. 446, 534-535, 713.

${ }^{48}$ Ibidem, pp. 617-618.

$49 * * *$ Molitfelnic, Bucureşti, Edit. Institutului Biblic şi de Misiune al Bisericii

Ortodoxe Române, 2006, pp. 227-229: „Care desfătare lumească...” (gl. 1),

„Vai câtă luptă...” (gl. 2); „Deşertăciuni sunt toate cele omeneşti...” (gl. 3);

„Unde este dezmierdarea cea lumească...” (gl. 4); „Adusu-mi-am aminte...”

(gl. 5); „Început şi temei...” (gl. 6); „După chipul şi după asemănarea Ta...”

(gl. 7); „Plâng şi mă tânguiesc...” (gl. 8). Stihirile de la glasurile 2 şi 4 nu se regăsesc în Octoih.

$50 * * *$ Triod (2010), pp. 701, 707, 712, 718, 724, 729, 734, 740.

51 Aceste tropare sunt indicate şi în Ceaslov, în cadrul troparelor Născătoarei de

Dumnezeu, cu precizarea că se cântă sâmbăta la fiecare glas atunci când este „Aliluia”, ***Ceaslov (2014), p. 244.

$52 * * *$ Tipicon (1816), p. 27. 
doar în capitolul 15 (slujbe cu Aliluia), însă este subînţeleasă şi în capitolul 14 (slujbe cu Dumnezeu este Domnul...), această litie fiind celebrată în fiecare zi de rând: „Şi obişnuita ieşire în pridvor. Şi se face litie pentru cei adormiţi" 53 .

Totuşi, având în vedere conţinutul capitolului al 16-lea ${ }^{54}$, este de presupus săvârşirea vineri seara a Parastasului Mare (Panihida), iar nu a Litiei mici pentru morţi, aşa cum se întâmplă în zilele de rând. Această celebrare ar putea fi un vestigiu al Pannyhisului solemn din cultul catedral, celebrat după Vecernie la Marea Biserică din Constantinopol în anumite zile ${ }^{55}$.

\subsection{Panihida şi Pavecerniţa}

Trebuie remarcat faptul că nici capitolul 14, nici capitolul 15 din Tipicon nu menţionează Pavecerniţa. Totuşi, aceasta nu înseamnă că Pavecerniţa este omisă, ci rubrica ar putea fi interpretată în două moduri:

(1) Ar putea fi subînţeleasă citirea Pavecerniţei în conformitate cu practica descrisă deja în relaţie cu zilele de rând (capitolul 11), unde se precizează:

„Iar după otpustul Vecerniei mergem la masă şi mâncăm cele puse înainte. Apoi, sculându-se paraeclesiarhul şi luând blagoslovenie, ieşind, loveşte în toacă. Şi intrând în pridvor, cântăm Pavecerniţa, după rânduială. La care cântăm canonul

${ }^{53}$ Cap. 11 (ibidem, p. 18).

54 „Vineri seara, după slobozenia Vecerniei, îmbrăcându-se preotul cu felonul şi diaconul cu stiharul, şi luând cădelniţa şi tămâie, ies în pridvor, mergând înaintea lor paraeclesiarhul cu sfeşnicul aprins. Şi urmăm după dânşii şi noi” (ibidem, pp. 28-29).

55 Spre ex., în ajunul marilor praznice, în prima săptămână din Postul Mare, în Săptămâna Sfintelor Pătimiri etc.; Juan MATEOS, Le Typicon de la Grande Église: ms. Sainte-Croix no. 40, Xe siècle, „Orientalia Christiana Analecta”, 166, Roma, PIO, 1963, pp. 14-15, 66-67, 202-209; cf. MAKARIOS Simonopetritul, Triodul explicat, trad. I.I. Ică jr, Sibiu, Edit. Deisis/Stavropoleos, 2008, p. 230-243; Juan MATEOS, Utrenia bizantină, col. „Liturgica”, 6, trad. Cezar Login, Cluj-Napoca, Edit. Renaşterea, 2009, pp. 5761 şi bibliografia citată în aparatul critic. 
de rugăciune al Preasfintei Născătoare de Dumnezeu, cel din Octoih, şi celelalte după obicei. Şi otpust. Iar întru celelalte zile cântăm Pavecerniţa cea mare." ${ }^{56}$

Conform acestui paragraf, după masa de seară se citeşte Pavecerniţa mică (dacă este slujbă cu Dumnezeu este Domnul...) sau Pavecerniţa Mare (dacă este slujbă cu Aliluia). Existenţa rubricilor care descriu slujbele cu Aliluia din sâmbetele a 2-a, a 3-a şi a 4-a din Postul Mare $^{57}$, în cadrul cărora se citeşte vinerea seara Pavecerniţa Mare ar sugera celebrarea acestei Pavecerniţa şi cazul sâmbetelor cu Aliluia ${ }^{58}$.

În acest caz, la Pavecerniţa Mare se cântă după primul Trisaghion troparele indicate la Vecernie ${ }^{59}$, după al doilea Trisaghion troparele de umilinţă, iar după al treilea Trisaghion condacul morţilor („Cu sfinţii odihneşte...”). Se poate presupune şi citirea canonului morţilor, de la glasul de rând, după modelul sâmbetelor din Postul Mare.

(2) Pavecerniţa este citită în particular, la chilie; există o situaţie similară în seara Marii Vineri, unde este prevăzută citirea Pavecerniţei la chilie sau, doar dacă doreşte cel mai mare, în biserică ${ }^{60}$. În acest caz s-ar putea presupune şi că Panihida (Parastasul) ar putea înlocui Pavecerniţa în biserică, deoarece relaţia dintre Pavecerniţa monahală şi Pannyhisul catedral este binecunoscută ${ }^{61}$.

În rânduiala actuală, Panihida păstrează atât elemente comune cu Pavecerniţa Mare (unele provenite din Pannyhisul cultului catedral; spre exemplu, Ps. 9062), cât şi numeroase elemente comune cu Utrenia monastică a sâmbetelor cu Aliluia (spre exemplu, Psalmul 118 şi binecuvântările morţilor).

Totuşi, celebrarea atât a Pavecerniţei Mari şi a Utreniei, cât şi a Panihidei ar putea fi un vestigiu al celebrării Panihidei nu în biserica „sobornicească” (catoliconul sau biserica mare a mânăstirii), ci în

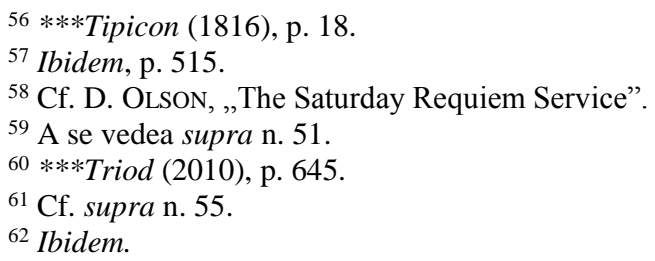


biserica din cimitir, în cazul existenţei unui astfel de paraclis. Absenţa unei biserici în cimitir ar fi putut conduce, în practică, la comasarea atât a Pavecerniţei cât şi a Panihidei în biserica principală, cu dublarea a numeroase elemente în cadrul aceleiaşi zile liturgice.

\subsection{Miezonoptica şi Ceasurile}

Miezonoptica nu este menţionată în Tipicon. Totuşi, existenţa unei Miezonoptici pentru sâmbete în Ceaslov ${ }^{63}$ disipează orice întrebare cu privire la existenţa acestei celebrări. Probabil nu este menţionată datorită faptului că se derulează exact aşa cum apare în Ceaslov.

Scurtele oficii ale Ceasurilor I (unit cu Utrenia), III, VI (precedând Dumnezeiasca Liturghie) şi IX (precedând şi unit cu Vecernia) se derulează după rânduiala din Ceaslov. Se citesc troparele comune ale sâmbetei: „Apostolilor, mucenicilor şi prorocilor...”, Slavă... „Pomeneşte, Doamne, ca un bun...”, Şi acum..., troparul Născătoarei de Dumnezeu, corespunzător fiecărui Ceas. După Trisaghion este prevăzut condacul: „Cu sfinţii odihneşte..." ${ }^{64}$. Totuşi, Ceaslovul propune pentru Ceasul I un alt condac: „Ca o pârgă a firii..." ${ }^{65}$ care dezvoltă a doua temă a sâmbetelor: pomenirea mucenicilor şi a tuturor sfinţilor.

\subsection{Utrenia}

Utrenia reprezintă oficiul cel mai complex al Liturghiei timpului. În cazul sâmbetelor cu Aliluia urmează rânduiala zilelor de rând, dar cu o serie de particularităţi. De asemenea, şi selecţia imnografiei este una specifică.

\subsubsection{Aliluia şi stihurile sale}

În cadrul acestui tip de celebrare, cântarea Dumnezeu este Domnul... este înlocuită de Aliluia (întreit), cântat de patru ori, intercalat cu următoarele trei stihuri psalmice:

$63 * * *$ Ceaslov (2014), pp. 41-51.

$64 * * *$ Tipicon $(1816)$, p. 28.

$65 * * *$ Ceaslov (2014), p. 94. 
Stih 1: Fericiţi cei pe care i-ai ales şi i-ai primit, Doamne, [locui-vor în curţile Tale] (Ps. 64, 4).

Stih 2: Şi pomenirea lor în neam şi în neam (cf. Ps. 101, 13 sau Ps. 134, 13).

Stih 3: Sufletele lor întru bunătăţi se vor sălăşlui [şi seminţia lor va moşteni pământul] $(P s .24,14)$.

Aceste stihuri se întâlnesc şi în rânduiala Parastasului şi a slujbei înmormântării, însă într-o ordine diferită: la sâmbetele cu Aliluia (inclusiv în Sâmbăta lăsatului sec de carne şi a Rusaliilor) şi la Parastasul Mare ordinea stihurilor este cea indicată mai sus (1-23); doar la înmormântare se inversează ordinea ultimelor două stihuri (1-3-2) şi, evident, textul este la singular, aşa cum apare în Psalmi ${ }^{66}$.

Cântarea Aliluia este urmată de troparele comune ale sâmbetei, indicate deja la Vecernie. Doar în Sâmbăta lăsatului sec de carne şi în Sâmbăta Rusaliilor se cântă troparul „Cel ce prin adâncul înţelepciunii...”, întâlnit astăzi şi la Parastas şi la Înmormântare.

\subsubsection{Psalmodia nocturnă: stihologiile Psaltirii}

Pentru Utrenia de sâmbătă este prevăzută întotdeauna citirea/cântarea catismelor a 16-a şi a 17-a (împărțite în câte trei stări). Recitarea fiecărei stihologii a Psaltirii este urmată de rostirea litaniei (mici) şi de sedelne a căror selecţie diferă în funcţie de tipul de celebrare folosit. După catisma a 16-a se cântă următoarele sedelne:

\begin{tabular}{|c|c|}
\hline Aliluia $^{67}$ & Dumnezeu este Domnul...68 \\
\hline Sedelnele Octoihului: & Sedelnele Octoihului: \\
\hline $\begin{array}{l}\text { - } 3 \text { sedelne ale mucenicilor (a 2- } \\
\text { a si a 3-a, prima nu se zice); }\end{array}$ & $\begin{array}{l}-3 \text { sedelne ale mucenicilor } \\
\text { (prima si a } 2-a \text { ); }\end{array}$ \\
\hline Minunat & - Slavă... Şi acum..., \\
\hline Duтnеzеи... (Ps. 67, 36) & Născătoarei de Dumnezeu. \\
\hline $\begin{array}{l}\text { - a 4-a sedealnă a mucenicilor } \\
\text { (sedealna Născătoarei de }\end{array}$ & \\
\hline
\end{tabular}

$66 * * *$ Molitfelnic (2006), p. 207.

$67 * * *$ Tipicon (1816), p. 27.

${ }^{68}$ Ibidem, p. 25. 
Dumnezeu de la primul rând de

sedelne din Octoih nu se zice);

- stih: Fericiţi cei pe care $i$-ai

ales... (Ps. 64, 4)

- sedealna morţilor;

- Slavă... Şi acum..., a

Născătoarei de Dumnezeu de la rândul al doilea de sedelne.

În cazul în care este folosit formularul liturgic cu Aliluia, Ps. 118 (catisma a 17-a) se cântă, nu se citeşte, în două stări, cu refrene intercalate între stihuri, modalitate de cântare care va fi analizată ulterior $)^{69}$. Cântarea Ps. 118 în cadrul celebrărilor de sâmbătă şi de duminică se datorează caracterului său anastasic, acest psalm, împărţit în trei antifoane, fiind cântat în cultul catedral constantinopolitan chiar şi la Utrenia Duminicii Sfintelor Paşti ${ }^{70}$. După catisma a 17-a se cântă următoarele sedelne:

\begin{tabular}{|c|c|}
\hline Aliluia & Dumnezeu este Dor \\
\hline Sedealna morților, & Sedel \\
\hline $\begin{array}{l}\text { Odihneşte, Mântuitorul nostru, cu } \\
\text { dreptii pe robii Tăi... }\end{array}$ & $\begin{array}{l}\text { - } 2 \text { sedelne ale mucenicilor (a 2- } \\
\text { şi a } 3-a \text { ); }\end{array}$ \\
\hline $\begin{array}{l}\text { Slavă... Şi acum..., a } \\
\text { Născătoarei de Dumnezeu: Cel ce } \\
\text { din Fecioară ai răsărit lumii... }\end{array}$ & $\begin{array}{l}\text { - sedealna morţilor; } \\
\text { - Slavă... Şi } \quad \text { acum .... }^{7} \text {, } \\
\text { Născătoarei de Dumnezeu. }{ }^{72}\end{array}$ \\
\hline
\end{tabular}

Cântarea sedelnelor este urmată de lecturi patristice sau aghiografice. După ultima lectură se citește $P s .50$.

\subsubsection{Psalmul 118 şi binecuvântările morţilor}

În cadrul formularului cu Aliluia, Ps. 118 (catisma a 17-a) nu se citeşte în trei stări, ci este cântată împărţită în două stări,

${ }^{69}$ A se vedea infra secțiunea 2.4.3.

${ }^{70}$ J. MATEOS, Typicon..., pp. 92-93.

71 Ibidem, p. 27.

72 Ibidem, p. 25. 
însoţite de refrene. Exact aceeaşi modalitate de cântare a Ps. 118 este întâlnită şi la Parastas. Starea întâi (vv. 1-93) se cântă (glasul al 5-lea) intercalat cu stihul: „Bine eşti cuvântat, Doamne...”. La finalul stării, ultimele două versete (92 şi 93 ) se unesc şi se cântă împreună, de trei ori, cu acelaşi refren. $\mathrm{Nu}$ se zice Slavă... Şi acum..., ci direct ectenia mică pentru morţi. Starea a doua (vv. 94-176) se cântă (glasul al 5-lea) intercalat cu stihul: „Mântuitorule, mântuieşte-mă”. La finalul stării, ultimele două versete (175 şi 176) se unesc şi se cântă împreună, de trei ori, cu acelaşi refren. Această stare este urmată de cântarea nemijlocită a binecuvântărilor morţilor.

În cadrul Parastasului, Ps. 118 este cântat în acelaşi mod. Însă refrenele stărilor se schimbă. Prima stare are ca refren stihul: „Pomeneşte, Doamne, sufletele robilor tăi”, iar a doua stare stihul: "Odihneşte, Doamne, sufletele robilor tăi". ${ }^{73}$

Modalitatea de cântare a Ps. 118 descrisă, cu refrene scurte intercalate între stihurile psalmului, cu repetarea ultimelor două versete şi absenţa doxologiei finale ne situează în afara modalităţii monastice de cântare a Psaltirii şi orientează spre Psaltirea de tip catedral, cântat ${ }^{74}$.

Spre exemplu, o manieră similară de cântare a unui psalm se întâlneşte în cadrul Pannyhisului catedral. Această celebrare se deschidea prin cântarea $P s .90$ - păstrat în deschiderea Panihidei sau Parastasului - cu stihul „Apără-mă, Doamne” folosit ca refren pentru fiecare verset al psalmului. La sfârşit, versetul 9b, „Pe Cel Preaînalt 1-ai pus scăpare ţie", era repetat de trei ori, cu acelaşi refren $^{75}$.

Ps. 118 este cântat şi la Utrenia duminicală şi la slujba înmormântării, însă cu unele particularităţi, refrenele fiind diferite.

$73 * * *$ Tipicon (1816), p. 29.

${ }^{74}$ A se vedea J. Mateos, Utrenia..., pp. 15-17; cf. Byron David Stuhlman, „The Morning Offices of the Byzantine Rite: Mateos Revisited", în Studia Liturgica 19(2)/1989, pp. 162-173.

75 Această repetare de trei ori a stihului la finalul Psalmului este atestată de mai

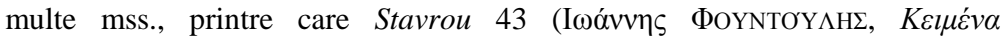

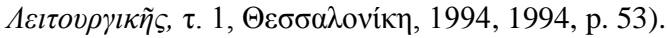




\subsubsection{Canoanele}

Canoanele Utreniei se cântă «pe 14», însoţite de stihurile Cântărilor lui Moise. În cazul în care este slujbă cu Dumnezeu este Domnul..., este folosită forma festivă, „Să cântăm Domnului...”, iar dacă este slujbă cu Aliluia, forma zilelor de rând, mai lungă, „Domnului să-I cântăm..."76.

În ambele situaţii se cântă trei canoane, a căror selecţie depinde de tipul de slujbă din Minei (simplă sau dublă) şi de hram (al Mântuitorului sau al Maicii Domnului, respectiv al unui Sfânt) ${ }^{77}$.

\begin{tabular}{|c|c|c|}
\hline & Slujbă simplă & Slujbă dublă \\
\hline Hramul unui sfânt & $\begin{array}{l}\text { - canonul sfântului } \\
\text { (cu irmosul), pe } 6 \text {; } \\
\text { - canonul hramului, } \\
\text { pe } 4 \text {; } \\
\text { - canonul Octoihului } \\
\text { (primul), pe } 4 \text {. }\end{array}$ & $\begin{array}{l}\text { - canonul primului } \\
\text { sfânt (cu irmosul), pe } 6 \text {; } \\
\text { - canonul sfântului al } \\
\text { doilea pe } 4 \text {; } \\
\text { - canonul Octoihului } \\
\text { (primul), pe } 4 \text {. }\end{array}$ \\
\hline $\begin{array}{l}\text { Hramul } \\
\text { Mântuitorului } \\
\text { sau al Maicii } \\
\text { Domnului }\end{array}$ & $\begin{array}{l}\text { - canonul hramului } \\
\text { (cu irmosul de două ori), } \\
\text { pe } 6 \text {; } \\
\text { - canonul sfântului, } \\
\text { pe 4; } \\
\text { - canonul Octoihului } \\
\text { (primul), pe } 4 \text {. }\end{array}$ & $\begin{array}{l}\text { - canonul hramului } \\
\text { (cu irmosul), pe } 4 \text {; } \\
\text { - canoanele sfinţilor, } \\
\text { pe } 6 \text {; } \\
\text { - canonul Octoihului } \\
\text { (primul), pe } 4 \text {. }\end{array}$ \\
\hline
\end{tabular}

\subsubsection{Laudele şi stihirile lor}

Stihirile cântate împreună cu Psalmii laudelor urmează acelaşi sistem întâlnit deja în cazul stihirilor de la Doamne, strigat-am....

\begin{tabular}{lc}
\hline Aliluia & Dumnezeu este Domnul... \\
\hline - se cântă psalmii laudelor (148- & $\begin{array}{c}\text { Dacă sfântul din Minei nu are } \\
\text { stihiri }\end{array}$ \\
\hline
\end{tabular}

${ }^{76}$ A se vedea capitolul 20 al Tipiconului (1816), p. 35; cf. Cezar Login, „Cântările lui Moise: stihologia canoanelor Utreniei”, în IDEM, Leitorugia, pp. 85-94. Pentru detalii, a se vedea ***Ірмологїй, Москва, 2015, pp. 106, 119.

77 ***Tipicon (1816), p. 24. 
- se pun 4 stihiri ale martirilor din Octoih

- Slavă..., stihira morţilor

- Şi acum..., a Născătoarei de Dumnezeu.
- se citesc psalmii laudelor (148-149-150)

- Slavă... Şi acum..., Ţie slavă se cuvine...

Dacă sfântul din Minei are stihiri

- se cântă psalmii laudelor (148149-150)

- se pun 4 stihiri din Minei

- Slavă... Şi acum..., a Născătoarei de Dumnezeu (din Minei)

Anexa Triodului ${ }^{78}$ conţine setul complet de patru stihiri ale mucenicilor pentru Laudele Utreniei. În Octoihul Mare, similar situaţiei de la Vecernie, setul de stihiri martirice este incomplet în majoritatea cazurilor (cifrele din tabel indică ordinea stihirilor din setul complet din anexa Triodului):

\begin{tabular}{cll} 
Glas & Stihiri martirice & \multicolumn{1}{c}{$\begin{array}{c}\text { Stihira morţilor } \\
\text { (a Sfântului Ioan } \\
\text { Damaschin) })^{79}\end{array}$} \\
\hline $\mathbf{1}$ & 4 stihiri martirice $(1-2-3-4)$ & 1 stihiră $^{80}$ \\
$\mathbf{2}$ & 3 stihiri martirice $(2-3-4)$ & 1 stihiră \\
$\mathbf{3}$ & 3 stihiri martirice $(2-3-4)$ & 1 stihiră \\
$\mathbf{4}$ & 3 stihiri martirice $(2-3-4)$ & 2 stihiri $^{83}$ \\
$\mathbf{5}$ & 3 stihiri martirice $(3-2-4)$ & 1 stihiră $^{84}$ \\
$\mathbf{6}$ & 4 stihiri martirice $(1-2-3-4)^{85}$ & - \\
$\mathbf{7}$ & 4 stihiri martirice $(2-3-4-1)$ & 1 stihiră $^{86}$ \\
$\mathbf{8}$ & 3 stihiri martirice $(2-3-4)$ & 1 stihirăa $^{87}$ \\
\hline
\end{tabular}

78 A se vedea, ***Triodul (2010), p. 697-742.

${ }^{79}$ Atribuirea apare în ***Tipicon (1816), p. 26.

$80 * * *$ Octoih Mare (1952), p. 99.

${ }^{81}$ Ibidem, p. 186.

${ }^{82}$ Ibidem, p. 273.

${ }^{83}$ Ibidem, p. 365.

${ }^{84}$ Ibidem, p. 455.

${ }^{85}$ Ibidem, pp. 542-543.

${ }^{86}$ Ibidem, pp. 626-627. 
Psalmii laudelor - şi stihirile lor, dacă există - sunt urmaţi de doxologia citită şi de ectenia cererilor.

\subsubsection{Stihirile stihoavnei laudelor}

La stihoavna laudelor se aplică acelaşi principiu ca şi în cazul stihoavnei Vecerniei. Stihirile sunt intercalate cu stihurile obişnuite ale celor adormiţi $i^{88}$ :

Stih 1: Fericiţi sunt cei pe care i-ai ales şi i-ai primit, Doamne (Ps. 64, 4).

Stih 2: Sufletele lor întru bunătăţi se vor sălăşlui şi seminţia lor va moşteni pământul (Ps. 24, 14).

Stih 3: Şi pomenirea lor în neam şi în neam (cf. Ps. 101, 13 sau Ps. 134, 13).

În funcţie de tipul de celebrare, există aceste posibilităţi:

\begin{tabular}{cc}
\hline Aliluia & Dumnezeu este Domnul... \\
\hline $\begin{array}{c}-4 \text { stihiri ale morţilor (ale lui } \\
\text { Teofan); }\end{array}$ & -3 stihiri ale mucenicilor cu \\
$-\quad$ Slavă... Şi acum ..., a a din Ceaslov (stih 1: Ps. 89, & $16-18 ;$ stih 2: Ps. 89, 19) \\
Născătoarei de Dumnezeu. & - Slavă..., a Sfântului (dacă \\
& există); \\
& - Şi acum..., a Născătoarei de \\
& Dumnezeu. \\
\hline
\end{tabular}

Stihirile morţilor - ale lui Teofan ${ }^{89}$ - alcătuiesc o serie completă, al cărui acrostih (în limba greacă) este: „Pe robii Tăi, Hristoase, scrie-i în cartea vieţii" ${ }^{\prime \prime}$, ceea ce corespunde

${ }^{87}$ Ibidem, pp. 722-723.

${ }^{88}$ Conform anexei din Triod, ultimul stih nu se zice, ci a 4-a stihiră a morţilor se cântă la Slavă.... Similar la glasul al 3-lea, unde există doar patru stihiri.

${ }^{89}$ Pentru compoziţiile lui Teofan, a se vedea Casimir EMEREAU, „Hymnographi byzantini Quorum nomina in litt eras digessit notulisque adornavit (continuatur)", în Ecclesia Orans 25(142)/1926, pp. 179-182.

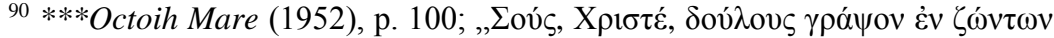

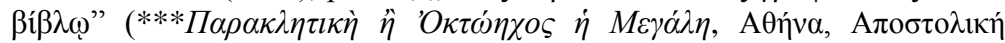
$\Delta$ เакоvía, 2008, p. 134). 
incipiturilor textului grecesc al stihirilor celor opt glasuri: $\langle\Sigma \mathrm{OY} \Sigma$ $\mathrm{X}$ (gl. 1)// PI $\Sigma$ T $\Delta$ [!] (gl. 2)// $\Delta \mathrm{OY} \Lambda$ (gl. 3)// OY $\Sigma$ ГP (gl. 4)// A $\Psi O N($ gl. 5)// EN Z $\Omega$ (gl. 6)// NT $\Omega N$ (gl. 7)// BIB $\Lambda \Omega \varsigma$ (gl. 8)». Singurul incipit care nu se încadrează în acrostih este cel al stihirii Născătoarei de Dumnezeu de la glasul al 2-lea, unde am fi aşteptat o stihiră care să înceapă cu litera „E”, iar nu cu „, $\Delta$ ”, ceea ce ne indică faptul că, la origine, aici era prevăzută o stihiră diferită. În anexa Triodului grecesc ${ }^{91}$, stihira corespunzătoare începe cu litera „E”. Chiar dacă în anexa Triodului românesc ${ }^{92}$ există o traducere fidelă a textului din Octoihul grecesc contemporan, totuşi, în Octoihul românesc întâlnim o variantă textuală a acestei stihiri. În sfârşit, Octoihul slavon ${ }^{93}$ are o altă stihiră, ce corespunde textului grecesc care are incipitul sugerat de acrostih.

\section{Concluzii şi posibile sugestii liturgice}

Slujbele cu Aliluia au părăsit peisajul liturgic în afara celor trei sâmbete ale Postului Mare. Reintroducerea lor în practică ar putea sublinia caracterul liturgic al sâmbetelor, iar materialul imnografic ar putea fi utilizat pentru o veritabilă cateheză liturgică cu privire la cei adormiţi.

Se poate observa instabilitatea Octoihului românesc în ceea ce priveşte stihirile martirice şi ale morţilor. Există diferenţe majore între glasuri şi, în acelaşi timp, pentru fiecare glas, între diferitele ediţii ale Octoihului. Pentru facilitarea utilizării celor două tipuri de formulare liturgice pentru sâmbete, s-ar putea organiza stihirile în aşa fel încât să fie distribuite similar pentru toate glasurile, în grupuri separate pentru celor două formulare liturgice posibile sâmbăta, pentru a fi mai uşor identificabile. Acest aspect este aplicabil atât stihirilor de la Vecernie cât şi celor de la Utrenie.

De asemenea, ar fi utilă o revizuire a traducerii stihirilor în concordanţă cu textul original. În mai multe cazuri, unul şi acelaşi

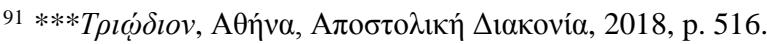

$92 * * *$ Triodul (2010), p. 709.

93 *** Окмжхь (осмогласникъ), Москва, 1981, рр. 343-344. 
text grecesc este tradus diferit în diverse cărţi de cult româneşti şi, uneori chiar în una şi aceeaşi carte. Acest fapt este evident în ceea ce priveşte textul stihirilor martirice şi ale morţilor, frecvent întâlnite în cadrul celebrărilor liturgice.

În sfârşit, ne putem întreba retoric: Se mai poate oare spera la o reaşezare a Parastasului (Panihidei) la locul său firesc, după finalul Vecerniei, loc ocupat de celebrarea catedrală de tip Pannyhis, care stă la baza acestei slujbe? În acest context, trebuie subliniat faptul că Dumnezeiasca Liturghie încununează celebrările liturgice ale zilei. După otpustul Liturghiei „nu mai are loc” nicio altă celebrare. Săvârşirea Parastasului după Liturghie comută atenţia credincioşilor asupra Parastasului care, astfel, ajunge să fie considerat „centrul” celebrărilor sâmbetelor în care se face pomenirea celor adormiţi.

$\cos 80$

\section{Bibliografie}

1. ***Ceaslov, Bucureşti, Edit. Institutului Biblic şi de Misiune Ortodoxă, 2014.

2. ***Liturghier, Bucureşti, Edit. Institutului Biblic şi de Misiune Ortodoxă, 2000.

3. ***Molitfelnic, Bucureşti, Edit. Institutului Biblic şi de Misiune al Bisericii Ortodoxe Române, 2006.

4. ***Octoih Mare, Bucureşti, Tipografia Cărţilor Bisericești, 1952.

5. ***Penticostar, Bucureşti, Edit. Institutului Biblic şi de Misiune al Bisericii Ortodoxe Române, 1999.

6. ***Penticostar, Bucureşti, Edit. Institutului Biblic şi de Misiune Ortodoxă, 2012.

7. ***Tipicon, Iaşi, Tipografia Sfintei Mitropolii, 1816.

8. ***Triodul, Bucureşti, Edit. Institutului Biblic şi de Misiune Ortodoxă, 2010.

9. ***Ірмологій, Москва, 2015.

10. *** Окмшхь (осмогласникъ), Москва, 1981.

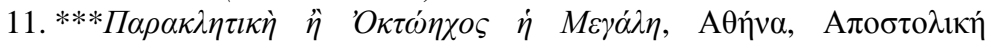
$\Delta$ เакоvía, 2008.

12. ***Триодь Цветная, Москва, 1635.

13. ***Тріод Постная, т. 2, Москва, 1992.

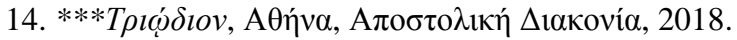


15. EMEREAU, Casimir, „Hymnographi byzantini Quorum nomina in litt eras digessit notulisque adornavit (continuatur)", în Ecclesia Orans, 25(142)/1926, pp. 179-182.

16. FlocA, Ioan N., Canoanele Bisericii Ortodoxe, Sibiu, 1992.

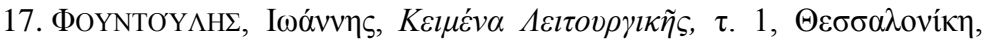
1994.

18. LoGIN, Cezar, Inainteprăznuirea Naşterii Domnului în ritul bizantin, col. „Liturgica”, 17, Cluj-Napoca, Edit. Renaşterea, 2020.

19. LoGIN, Cezar, Leitorugia: teologie şi practică liturgică, col. „Liturgica”, 14, Cluj-Napoca, Edit. Renaşterea, 2014.

20. MAKARIOS SimONOPETRITUL, Triodul explicat, trad. I.I. Ică jr, Sibiu, Edit. Deisis/Stavropoleos, 2008.

21. Mateos, Juan, Le Typicon de la Grande Église: ms. Sainte-Croix no. 40, Xe siècle, col. „Orientalia Christiana Analecta, 166, Roma, PIO, 1963.

22. MAteos, Juan, Utrenia bizantină, col. „Liturgica”, 6, trad. Cezar Login, Cluj-Napoca, Edit. Renaşterea, 2009.

23. NeCUla, Nicolae D., Tradiţie şi înnoire în slujirea liturgică, vol. I, Edit. Trinitas, Bucureşti, 2014

24. Olson, Daniel, „The Saturday Requiem Service”, în Peter FeKUla, Matthew WiLliams, The Order of Divine Services according to the usage of the Russian Orthodox Church, St. John of Kronstadt Press, Liberty, $2009^{2}$.

25. Stuhlman, Byron David, ,The Morning Offices of the Byzantine Rite: Mateos Revisited", în Studia Liturgica, 19(2)/1989, pp. 162173. 